\title{
Impact of air-sea coupling on Northern Hemisphere summer climate and the monsoon-desert teleconnection
}

\author{
Albert Ossó $^{1}\left[\right.$ Len Shaffrey $^{1} \cdot$ Buwen Dong $^{1} \cdot$ Rowan Sutton $^{1}$
}

Received: 23 June 2018 / Accepted: 6 June 2019 / Published online: 15 June 2019

(c) The Author(s) 2019

\begin{abstract}
Previous studies have established the existence of a large-scale teleconnection between ascent in the South Asian Summer Monsoon and subsidence over the Mediterranean (known as "the monsoon-desert mechanism"). Improving the representation of this mechanism could potentially improve the skill of seasonal forecasts for European summer weather patterns. In this study, the impact of air-sea coupling on the NH summer climate and the representation of the monsoon-desert mechanism is analysed in two 45-year experiments with the Met-Office Unified Model. In the first coupled experiment, the atmosphere is allowed to freely interact with a high-vertical-resolution mixed-layer ocean model. The diagnosed daily SSTs from this experiment are then used to force an atmosphere-only uncoupled experiment. The two experiments have a similar mean state, but the coupled experiment has a substantially more realistic representation of interannual precipitation variability over the Indian Summer Monsoon region. The coupled experiment can capture the observed westward propagating Rossbywave trains excited by the Indian Summer Monsoon, while in the uncoupled experiment the Rossby-wave response is more local. It is shown that in the coupled experiment more moisture is transported inland and monsoon precipitation reaches further north, which favours westward Rossby wave propagation. Finally, evidence is shown that the coupled experiment can capture the observed interannual relationship between the Indian Summer Monsoon precipitation and precipitation over the Balkans/Black Sea region.
\end{abstract}

Keywords Air-sea interactions · Climate variability $\cdot$ Summertime tropical-extratropical teleconnections · Indian summer monsoon

\section{Introduction}

Since the pioneering work of Bjerknes $(1964,1972)$ and Wyrtki $(1973,1974)$, there is now substantial evidence that the representation of air-sea interactions is essential to capturing a large range of atmosphere and climate phenomena in climate models. In the tropics, a good representation of air-sea interactions has proved essential for capturing the atmospheric variability over the Pacific Ocean (Wu and Kirtman 2005; Wang et al. 2005), the observed sea surface temperature (SST)-rainfall relationship (Rajendran and Kitoh 2006), as well as for improving the simulation of the Madden-Julian Oscillation (MJO) (Woolnough et al. 2007; DeMott et al. 2014). In the extratropics, high-frequency SST

Albert Ossó

a.osso@reading.ac.uk

1 NCAS-Climate, University of Reading, Reading, UK variations are primarily driven by atmospheric circulation and the atmospheric response to SST is relatively shallow and weak (e.g., Hoskins and Karoly 1981). However, recent analyses using high-resolution satellite observations and numerical models suggest that extratropical SST, and in particular changes on SST gradients, have an impact on the extratropical atmospheric circulation, both in winter (e.g. Xie 2004; Nakamura et al. 2008; Woollings et al. 2008; Wills et al. 2016) and in summer (Sutton and Hodson 2005; Sutton and Dong 2012; Dong et al. 2013; Ossó et al. 2018).

Air-sea interactions are also essential to realistically represent interannual variability. SST has long been recognized as a critical driver of interannual tropical variability, both in models and observations (Graham et al. 1993; Lau and Nath 1994; Trenberth et al. 1998; Wallace et al. 1998; Sutton and Hodson 2003). To assess the importance of these drivers, a common modelling approach is to force an atmospheric general circulation model (AGCM) with observed SST (e.g., Gates et al. 1999 and reference therein). This approach, although highly 
valuable, has the caveat of suppressing the atmospheric feedback onto the SSTs, which in some areas can lead to important biases (Kitoh and Arakawa 1999; Lau and Nath 2000; Wu and Kirtman 2004; Wu and Kirtman 2005). In particular, coupled climate models have been shown to perform better in simulating the Indian Summer Monsoon (ISM) variability than atmosphere-only models with prescribed SSTs (Krishna Kumar et al. 2005).

An additional question is the potential impact of air-sea interactions on the representation of tropical-extratropical teleconnections. Such teleconnections have been extensively studied in the context of the tropical MJO and the wintertime North Atlantic Oscillation (e.g., Cassou 2008) and for the impact of ENSO on the wintertime mid-latitude circulation (e.g., Ineson and Scaife 2009). However, the impact of air-sea interactions on important $\mathrm{NH}$ summer teleconnections such as the monsoon-desert teleconnection (Rodwell and Hoskins 1996) have received less attention.

Rodwell and Hoskins (1996) (hereafter RH96) used an idealized model to show that remote diabatic heating in the ISM forces a westward propagating Rossby wave that interacts with the southern flank of the mid-latitude westerlies. This interaction causes descent over the eastern Sahara and the Mediterranean, exacerbating the warm and dry conditions over this area during summer. This mechanism is referred to as the monsoon-desert teleconnection. Further evidence of the existence of this teleconnection has been found in atmospheric reanalysis data (Tyrlis et al. 2013). In addition, Cherchi et al. (2014) analysed the ability of the CMIP5 models (Fifth Coupled Model Intercomparison Project) to represent the physical mechanisms involved in the monsoon-desert teleconnection. They showed that most CMIP5 models underestimate the ISM-related diabatic heating at upper levels, while they over-estimate it at lower levels, resulting in a weaker forced response and weaker descent over the Mediterranean.

This study aims to investigate the impact of air-sea interactions on the $\mathrm{NH}$ summer atmospheric mean state, interannual variability, and the monsoon-desert teleconnection. The paper is organized as follows: Sect. 2 describes the model, observational data and methods. Section 3 describes the effects of coupling on the mean state and interannual variability of the atmosphere. Section 4 analyzes the impact of air-sea interactions on tropical precipitation. Section 5 explores the impact of air-sea coupling on the model representation of the monsoon-desert teleconnection. A summary is provided in Sect. 6 .

\section{Model, data and methods}

\subsection{MetUM-GOML1 model description and experimental design}

The coupled simulation was carried out using the Global Ocean Mixed Layer coupled configuration version 1 of the Met Office HadGEM3 Unified Model (MetUM-GOML1; Klingaman et al. 2011; Hirons et al. 2015), comprising the Met Office HadGEM3 Global atmosphere 3.0 (Arribas et al. 2011; Walters et al. 2011) coupled to the Multi-Column K Profile Parameterization (KPP) ocean. MetUMGOML1 provides a high-resolution, vertically resolved upper layer ocean model with limited computational cost (since there is no representation of horizontal ocean dynamics). This allows long climate integrations with a high-frequency coupling (the atmosphere and ocean are coupled every $3 \mathrm{~h}$ ) to be performed with reasonable computing costs. Furthermore, the MetUM-GOML1 model can be constrained to any desired ocean climatology by prescribing depth-varying temperature and salinity tendencies representative of the mean ocean advection. This methodology has the advantage of ensuring that the coupled model has very small SST biases compared with a fully coupled AOGCM (Hirons et al. 2015). Temperature and salinity tendencies are calculated by strongly relaxing a MetUM-GOML1 simulation (hereafter Exp0) to a 3D monthly mean ocean analysis averaged over 1994-2011 from the Met Office ocean analysis (Smith and Murphy 2007). We then performed a 50-year long MetUMGOML1 coupled experiment where the atmosphere is allowed to freely interact with the mixed-layer KPP ocean model. MetUM-GOML1 is forced with ocean tendencies from Exp0, and the greenhouse gases concentrations, aerosols emissions, and sea-ice concentration averaged over the period 1994-2011. Finally, daily SSTs diagnosed from the coupled experiment are used to force another 50-year atmosphere-only experiment using the HadGEM3. External forcing (GHGs, aerosols, etc.) in the atmosphere-only uncoupled experiment are prescribed in the same way as in the coupled experiment. Detailed experiment designs were documented in Dong et al. (2017). The first 5 years of each experiment are discarded and only the last 45 years are used in the analysis.

\subsection{Observational data}

To evaluate the model experiments, we use monthly-mean SST from the HadISST dataset for the 1994-2011 period (Rayner et al. 2003). Monthly-mean $250 \mathrm{hPa}$ geopotential height $\left(\mathrm{Z}_{250}\right)$, zonal $(\mathrm{U})$ and meridional $(\mathrm{V})$ wind output 
at $250 \mathrm{hPa}$ and $925 \mathrm{hPa}$ is obtained from the ECMWF Interim Reanalysis (ERA-Interim) for the 1979-2015 period (Dee et al. 2011). Finally, monthly-mean rainfall data for the same period is obtained from the Global Precipitation Climatology Project (GPCP) version 2.2 (Adler et al. 2003).

\subsection{Methods}

All results are based on the monthly-mean output from the model and observational datasets. June-July-August (JJA) mean anomalies of $\mathrm{Z}_{250}, \mathrm{U}, \mathrm{V}, \mathrm{SST}$ and precipitation are calculated by subtracting the corresponding long-term mean seasonal cycle from the data. The observational data (ERA-Interim and the GPCP dataset) are linearly detrended to remove the influence of the trends in the results. Interannual variability is represented as the standard deviation of the corresponding JJA anomalies. To test whereas a difference in the standard deviation is statistically significant, we use the non-parametric Ansari-Bradley test (Ansari and Bradley 1960; Lunneborg 2005) with the null hypothesis that the variances are equal. This test has the advantage of not assuming the data to be normally distributed. Finally, the statistical significance of linear regression and correlation coefficients are assessed using the methodology outlined by Santer et al. (2000) that accounts for the autocorrelation of the time series. In all statistical tests, a 95\% significance level is used.

\section{Results}

In Sect. 3.1 we analyse the impacts of air-sea interactions on the representation of the atmosphere mean JJA state. The impact of air-sea interactions on the interannual variability is assessed in Sect. 3.2.

\subsection{Impact of air-sea interactions on the JJA climatological mean state}

Figure 1 shows the JJA climatological mean patterns of precipitation and $\mathrm{U}_{250}$ for the ERA-Interim and GPCP data (Fig. 1a), the coupled (Fig. 1b), and the uncoupled experiment (Fig. 1c). Model biases of SST, precipitation and $\mathrm{U}_{250}$ are shown in Fig. 2a, c, e for the coupled experiment and in Fig. 2b, d, f for the uncoupled one. By construction (see Sect. 2.1), both experiments have the same mean SST biases. In general, SST biases in the model simulation are much smaller (typically within $\pm 0.5^{\circ} \mathrm{C}$ ) than those in CMIP5 models (Wang et al. 2014). However, they are some relative large biases in midlatitudes, characterized by cold anomalies of about $0.4-0.8^{\circ} \mathrm{C}$ over the North Atlantic and western North Pacific and warm anomalies of $\sim 0.4{ }^{\circ} \mathrm{C}$ over the subpolar gyre of the North Atlantic (Fig. 2a, b). The precipitation biases are similar between the coupled and uncoupled experiments. Both exhibit wet biases over the equatorial Indian Ocean, the Pacific Ocean ITCZ and the Caribbean Sea in JJA. Dry biases are seen over the Indian continent and the southern tropical Indian Ocean (Figs. 2c, d). Similar annual mean biases in precipitation have been reported in the MetUM-GOML1 model (Klingaman et al. 2011) and have been attributed to a long-standing issue of the MetUM (e.g., Hewitt et al. 2011) that is also present in most of the CMIP3 (Kripalani et al. 2007) and CMIP5 models (Ringer et al. 2006; Sperber et al. 2012; Preethi et al. 2017). Both experiments exhibit a westerly wind bias in the upper troposphere between $10^{\circ} \mathrm{N}-20^{\circ} \mathrm{N}$ in the Central Pacific and in the Caribbean Sea that extends across the tropical Atlantic in the coupled experiment (Figs. 2e, f). This wind bias is probably associated with the excessive precipitation over the tropical western Pacific shown in both experiments (Fig. 2c, d). The North Atlantic eddy-driven jet is biased poleward (about $7.5^{\circ}$ for the coupled experiment and $5^{\circ}$ for the uncoupled one) (Fig. 2e, f). The eddy-driven jet bias might be associated with extratropical SST biases that show cold anomalies along the Gulf Stream and warm anomalies over the North Atlantic subpolar gyre (Fig. 2a, b) resulting in a weaker meridional SST gradient than in observations. A weak meridional SST gradient during summer in the North Atlantic has been associated with a poleward displacement of the jet (e.g., Gastineau and Frankignoul 2015; Ossó et al. 2018). The eddy-driven jet in North East Asia is also biased poleward in both experiments (about $2.5^{\circ}$ in the coupled experiment and about $5^{\circ}$ in the uncoupled experiment (Fig. 2e, f). Overall, the biases of MetUM-GOML1 are of similar magnitude to those generally found in most of the state-of-the-art climate models (e.g., Randall et al. 2007; Bader et al. 2008).

To determine the impact of air-sea interactions on the representation of the atmospheric JJA mean state in MetUMGOML1, Fig. 3a shows the difference in $\mathrm{Z}_{250}$ and precipitation between the coupled and uncoupled experiments, while Fig. $3 b$ shows the differences in $U_{250}$. The spatial pattern of JJA precipitation is similar between the two experiments, but some differences in magnitude are apparent (Fig. 3a). The JJA precipitation across the tropics is generally lower in the coupled experiment, but the differences are statistically significant only in a few regions. For example, in the coupled experiment the precipitation is approximately $10 \%$ lower over Tropical Africa and about 5\% lower over North India. In contrast, precipitation over the Maritime (MC) continent is about $5 \%$ higher.

The coupled experiment exhibits lower $Z_{250}$ than the uncoupled experiment across most of the tropical and subtropical NH. The differences in the Atlantic $\mathrm{U}_{250}$ (Fig. 3b) are consistent with $\mathrm{Z}_{250}$, showing upper-level westerly anomalies in 
Fig. 1 Seasonal-mean (JJA) precipitation [shading $\left(\mathrm{mm} \mathrm{day}^{-1}\right)$ ] and $\mathrm{U}_{250}$ [solid contours $\left(\mathrm{m} \mathrm{s}^{-1}\right)$ ] for a the GPCP and ERA Interim datasets, $\mathbf{b}$ the coupled and $\mathbf{c}$ the uncoupled experiment (a) Observations

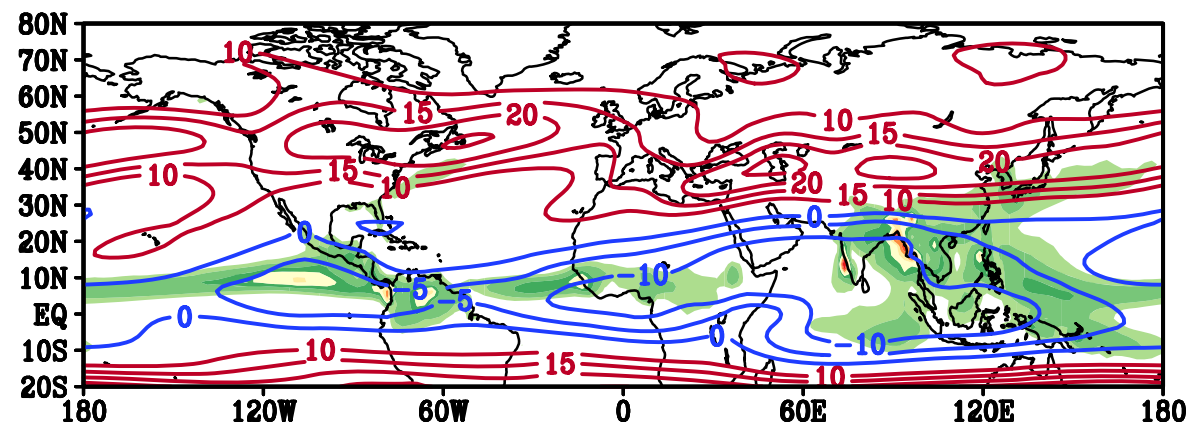

(b)

Coupled

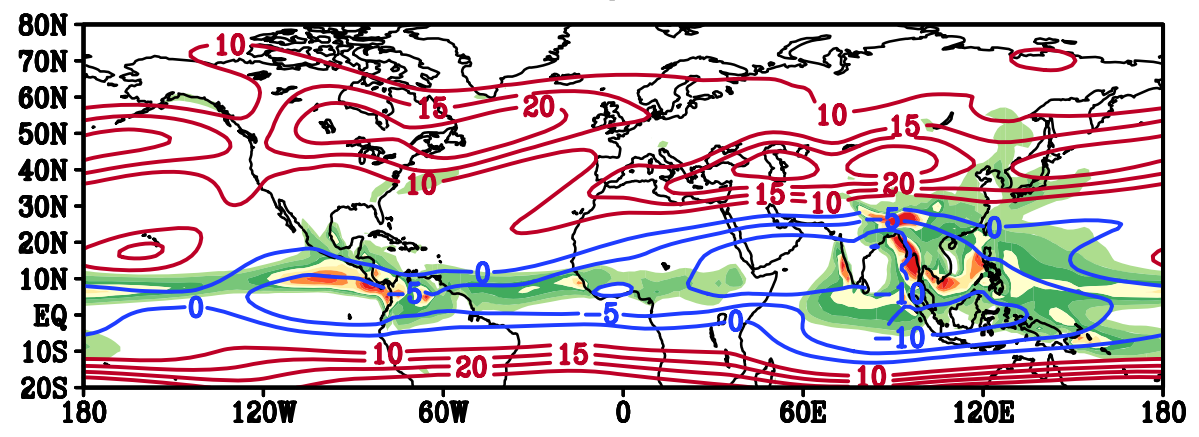

(c)

Uncoupled
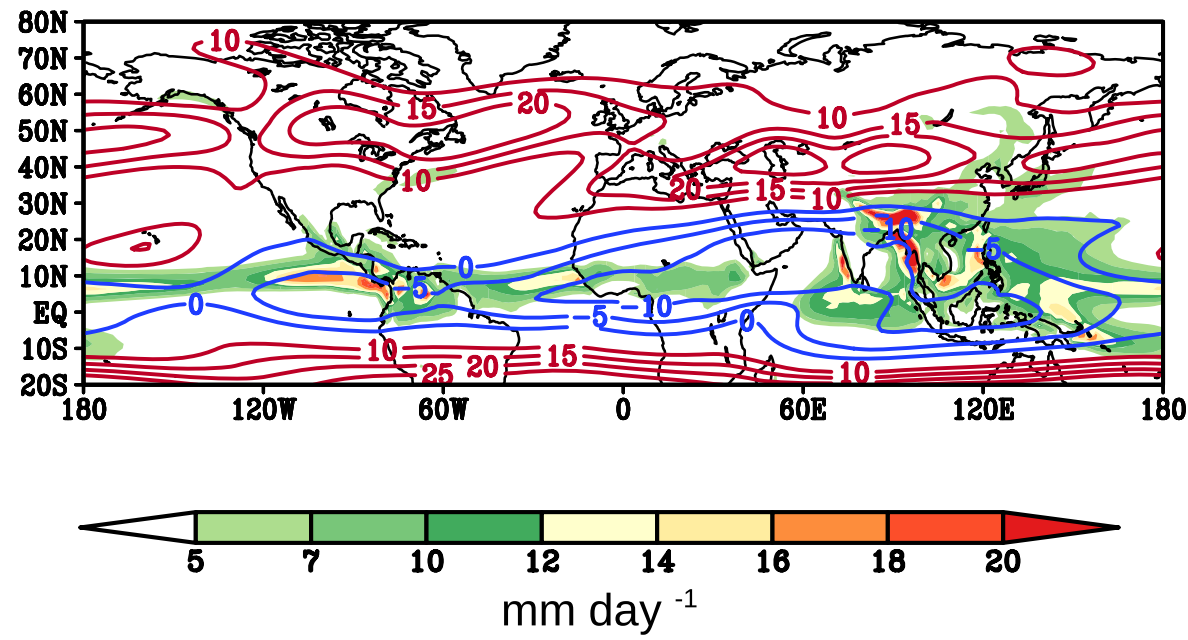

the tropics, a weakening of the westerlies around $45^{\circ} \mathrm{N}$ and a strengthening around $65^{\circ} \mathrm{N}$. These features are consistent with a poleward displacement of the extratropical eddy-driven jet. A vertical profile of the zonal mean zonal wind (figure not shown) indicates a weakening of the Hadley Circulation in the coupled experiment relative to the uncoupled experiment. The reduction in the strength of the Hadley Circulation and the associated zonal wind changes are consistent with air-sea interactions tending to dry and cool the lower tropical troposphere possibly as a result of slightly shallower convection
(Hirons et al. 2015). The displacement of the eddy-driven jet in the coupled experiment may be related to difference in the mean values and variability of tropical precipitation between the coupled and uncoupled experiments.

\subsection{Impact of sea-air interactions on JJA interannual variability}

Figure 4 shows the standard deviation of seasonal-mean (JJA) precipitation and $\mathrm{Z}_{250}$ anomalies for the observations 
(a)

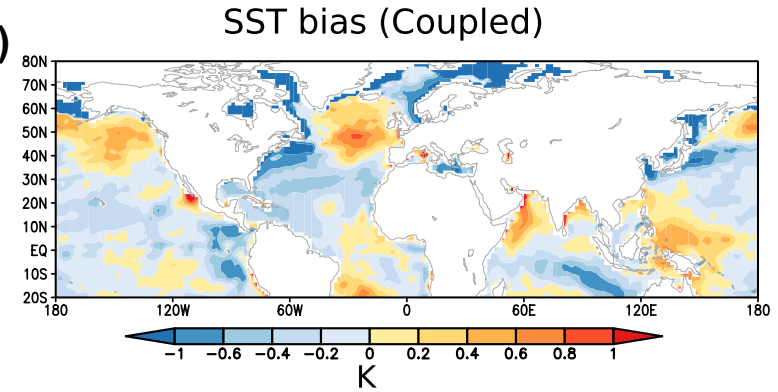

(c)

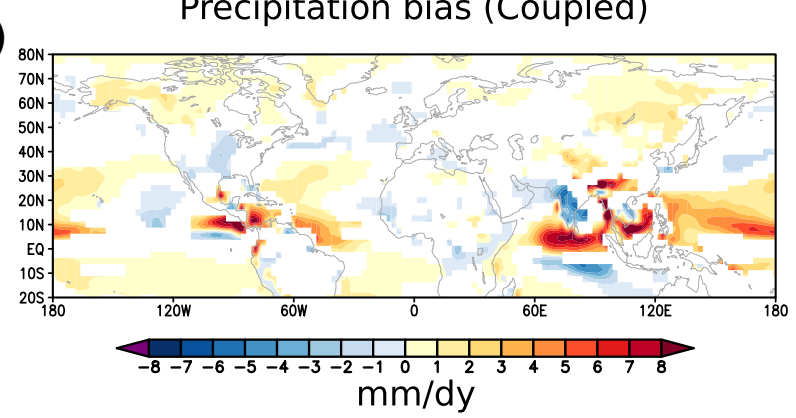

(e)

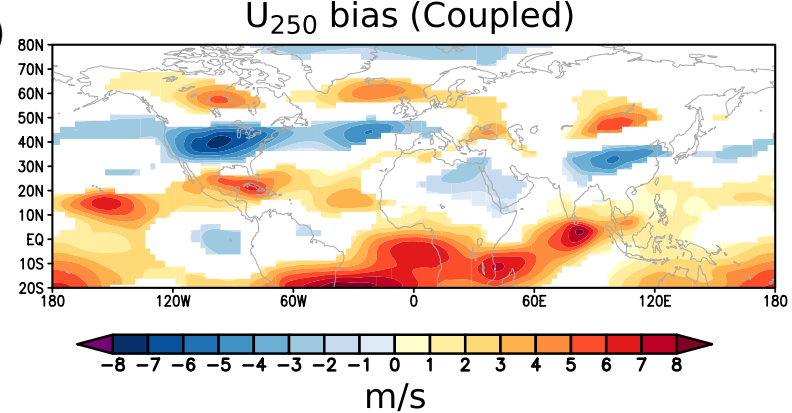

Fig. 2 (Left column) Seasonal-mean (JJA) bias of the coupled experiment against the HadISST, ERA-Interim and GPCP datasets for a SST [shading $(\mathrm{K})]$, c precipitation [shading $\left(\mathrm{mm} \mathrm{day}^{-1}\right)$ ] and $\mathbf{e} \mathrm{U}_{250}$

(Fig. 4a), and the coupled and uncoupled experiments (Figs. 4b, c respectively). Differences between the coupled and uncoupled experiments are shown in Fig. 5. In the NH tropics, sea-air interactions result in much weaker interannual JJA precipitation variability. The reduction is particularly large in the areas of the ISM, the MC and off the coast of Central America and West Africa, where the interannual variability of precipitation in the coupled experiment is about half the size that in the uncoupled one (Fig. 5).

In the extratropics, the patterns of $Z_{250}$ variability are similar between the coupled and uncoupled experiments, exhibiting both two maxima located near the exit regions of the North Atlantic and North Pacific eddy-driven jets (Fig. 4). However, there are some significant differences between the two experiments. Firstly, the North Atlantic maximum in the coupled experiment is centered over north-western Europe, suggesting that eddy-driven jet variability might be larger at the jet exit region, while in the (b)

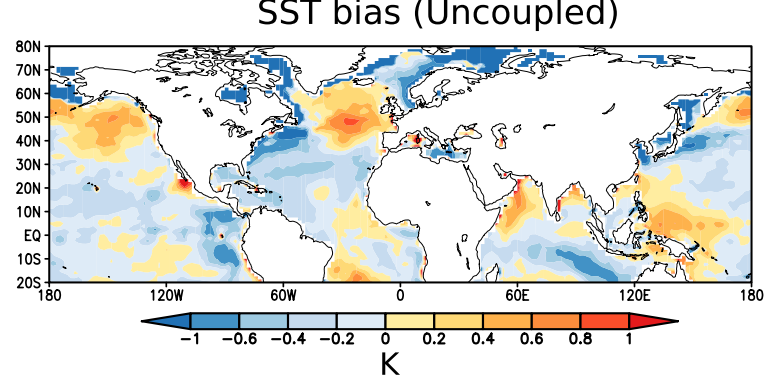

(d)

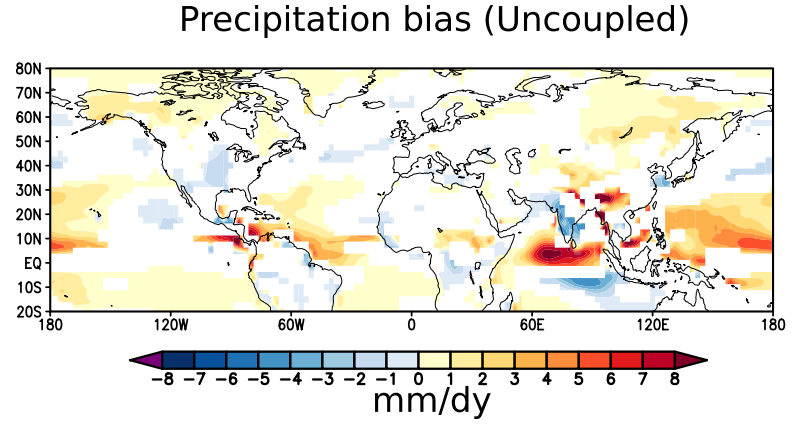

(f)

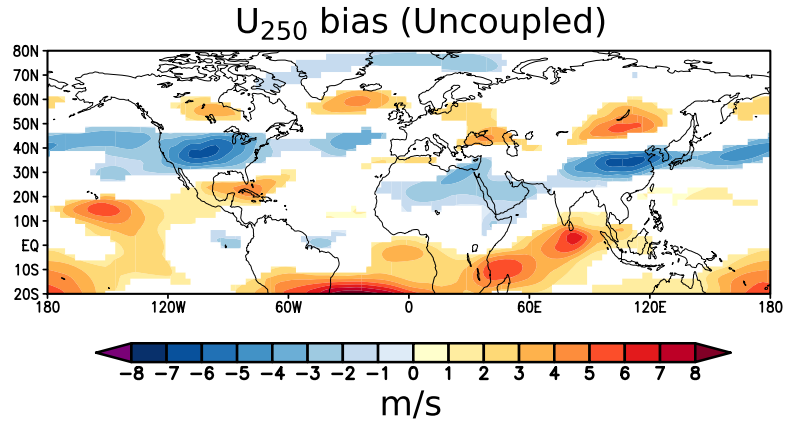

[shading $\left.\left(\mathrm{m} \mathrm{s}^{-1}\right)\right] . \mathbf{b}, \mathbf{d}, \mathbf{f}$ like $\mathbf{a}, \mathbf{c}$ and $\mathbf{e}$ but for the uncoupled experiment. Only the differences that are statistically significant at the $95 \%$ level are shown

uncoupled experiment the maximum is zonally elongated over the North Atlantic and centered further west, suggesting more longitudinal coherent Atlantic eddy-driven jet variability. Figure 5 shows that the $Z_{250}$ variability in the coupled experiment is stronger over the North Pacific Ocean, northern Europe and to the east of Greenland (not statistically significant) and weaker over Northern Canada and West of the UK. This might suggest an increase of the blocking frequency in these regions. Hirons et al. (2015) showed that including air-sea coupling does indeed increase the frequency of blocking in spring to the east of Greenland and improves the agreement with observations. Finally, $\mathrm{Z}_{250}$ interannual variability over the Mediterranean area is significantly smaller in the coupled experiment. A PDF of the $\mathrm{Z}_{250}$ anomalies over the Mediterranean (not shown) shows a decrease of both positive and negative extreme anomalies in the coupled experiment relative to the uncoupled experiment. This reduction could be the 
Fig. 3 Seasonal-mean (JJA) difference between the coupled and uncoupled experiments for a precipitation [shading $\left(\mathrm{mm} \mathrm{day}^{-1}\right)$ ] and $\mathrm{Z}_{250}$ [contours (m)] and $\mathbf{b} \mathrm{Z}_{250}$ [contours (m)] and $\mathrm{U}_{250}$ [shading $\left(\mathrm{m} \mathrm{s}^{-1}\right)$ ]. In a all precipitation differences shown are statistically significant at the 95\% level. Yellow shading in a denotes statistically significant $Z_{250}$ differences. In b only the $\mathrm{U}_{250}$ differences that are statistically significant are display. No significance for $\mathrm{Z}_{250}$ is shown in $\mathbf{b}$
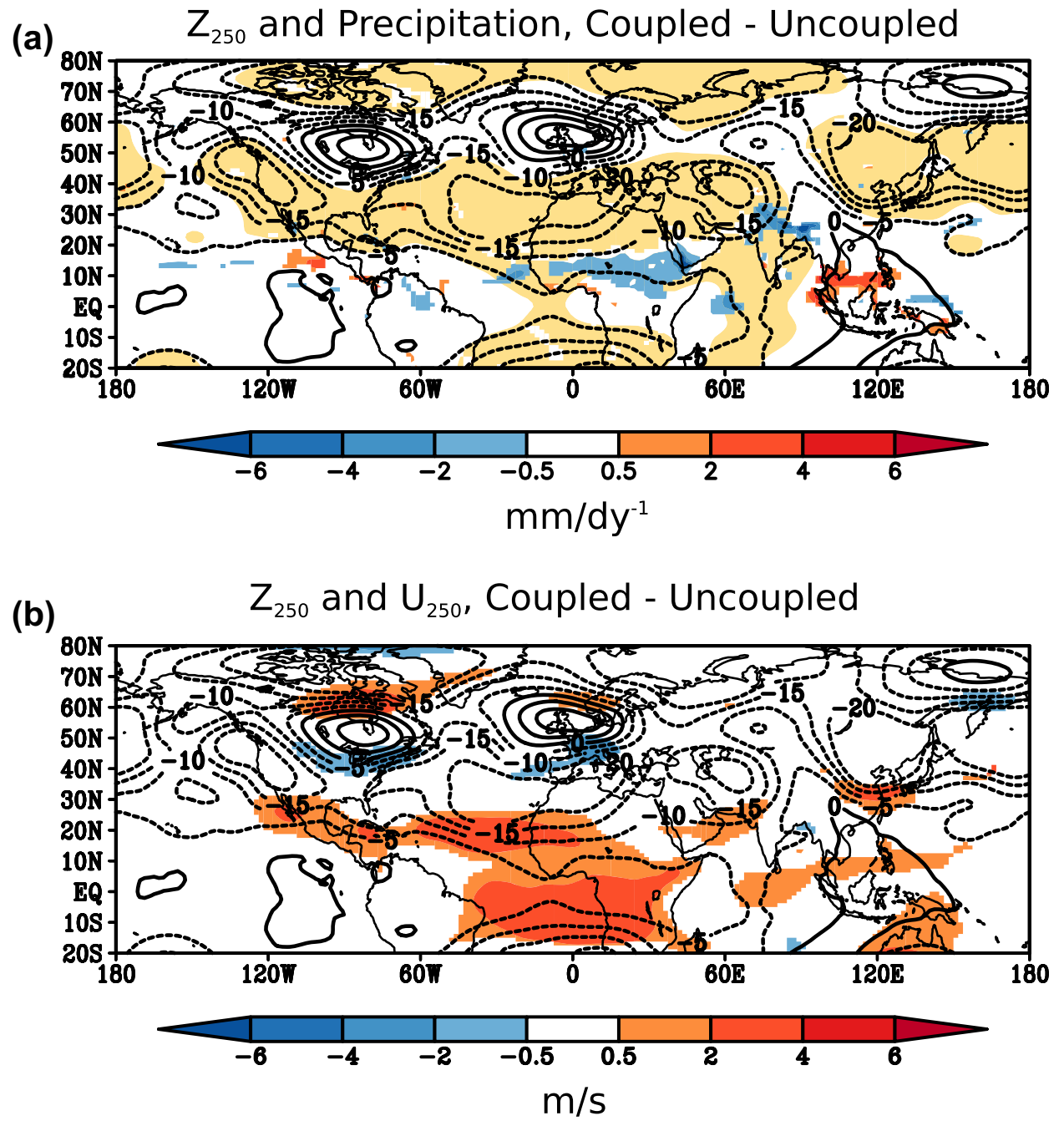

consequence of air-sea interactions tending to reduce the intensity of Mediterranean convection in a similar way as in the tropics.

Figure 6 shows the biases of the standard deviation of seasonal-mean (JJA) precipitation and $\mathrm{Z}_{250}$ anomalies for the coupled (Fig. 6a) and uncoupled (Fig. 6b) experiments against the ERA-Interim and GPCP datasets. In the uncoupled experiment, the interannual precipitation variability over the Indian subcontinent, the tropical Indian Ocean, the South China Sea, and the West Tropical Pacific Ocean is approximately two times larger than in the observations. In contrast, the biases in interannual precipitation variability in the coupled experiment are much smaller, with almost no statistically significant bias in the above areas. The reasons for the difference between the coupled and uncoupled experiment will be explored in the following section. Finally, Fig. 6 shows that both experiments underestimate the $Z_{250}$ variability over the northeast Atlantic and the North Pole and overestimate it near the south coast of Alaska.

\section{Tropical SST-precipitation covariance}

To gain further insight into the impact of air-sea interaction on precipitation, this section investigates how air-sea interaction affects the SST-precipitation covariance of the two experiments. Hirons et al. (2018) used a similar configuration of the MetUM-GOML1 to investigate the impact of air-sea interactions on intraseasonal variability. Their results show that air-sea interactions damp the extreme tropical precipitation response to a given SST anomaly. They suggest that the damped response is due to a negative local thermodynamic feedback in the coupled system through convection, surface fluxes, and SST: An increase in SST intensifies convection, which increases the fluxes out of the ocean cooling the initial SST and damping convection. Another negative feedback by which air-sea interactions may also damp local precipitation is via changes in cloud cover: an increase in SST intensifies convection, which increases cloud cover that reduces the amount of radiation reaching the surface and cooling the first SST anomaly. One way to analyse a 
Fig. 4 Standard deviation of seasonal-mean (JJA) precipitation [shading $\left.\left(\mathrm{mm} \mathrm{day}^{-1}\right)\right]$ and $\mathrm{Z}_{250}$ anomalies (blue contours (meters), $>35$ highlighted by bright blue) for a ERA- Interim and GPCP datasets, $\mathbf{b}$ the coupled and $\mathbf{c}$ the uncoupled experiment. The black dotted line indicates the zero contour of the climatological mean JJA $\mathrm{U}_{250}$
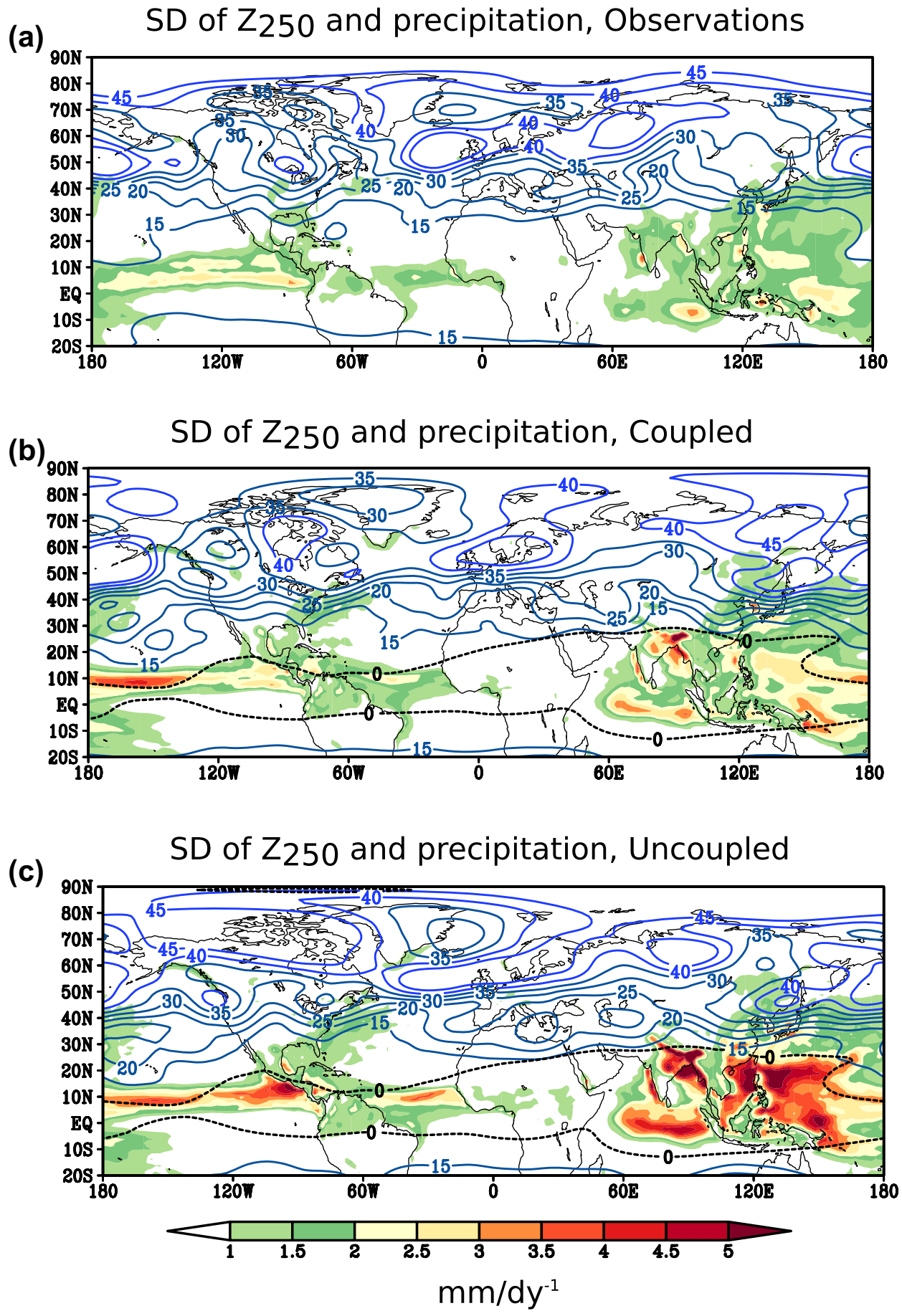

possible ocean impact on precipitation is by calculating the correlation pattern between the local SST and precipitation anomalies. In this analysis, a positive correlation between precipitation and SST suggests that the SSTs are forcing the atmosphere, while a negative correlation would suggest that the atmosphere is forcing the SSTs (e.g., Wang et al. 2005).

Following this methodology, we examine local correlations between JJA precipitation and SST anomalies for the observations and the coupled and uncoupled experiments (Fig. 7a-c respectively). Large and statistically significant negative correlations are apparent in both the observations (Fig. 7a) and the coupled experiment (Fig. 7b) around the western Pacific Ocean, suggesting that over these areas the atmosphere is locally forcing the SSTs. These are areas of warm SSTs and vigorous deep convection where SST anomalies can induce a strong atmospheric response that can feedback onto the local (for example, through the negative feedbacks discussed above) and near SSTs via large-scale subsidence. The subsidence 
Fig. 5 Seasonal-mean (JJA) standard deviation difference between the coupled and uncoupled experiments for precipitation [shading $\left.\left(\mathrm{mm} \mathrm{day}^{-1}\right)\right]$ and $\mathrm{Z}_{250}$ [contours (m)]. Only precipitation differences that are statistically significant at the $95 \%$ level are shown. Light yellow shading indicates $Z_{250}$ contours that are statistically significant at the $95 \%$ level
Fig. 6 Seasonal-mean (JJA) standard deviation bias against the GPCP and ERA-Interim datasets of precipitation [shading $\left.\left(\mathrm{mm} \mathrm{day}^{-1}\right)\right]$ and $\mathrm{Z}_{250}$ [contours (m)] for a the coupled and $\mathbf{b}$ the uncoupled experiments. Only the differences of precipitation that are statistically significant at the $95 \%$ level are shown. $Z_{250}$ differences that are statistically significant at the 95\% level are highlighted with light yellow shading
SD of $Z_{250}$ and Precipitation, Coupled - Uncoupled

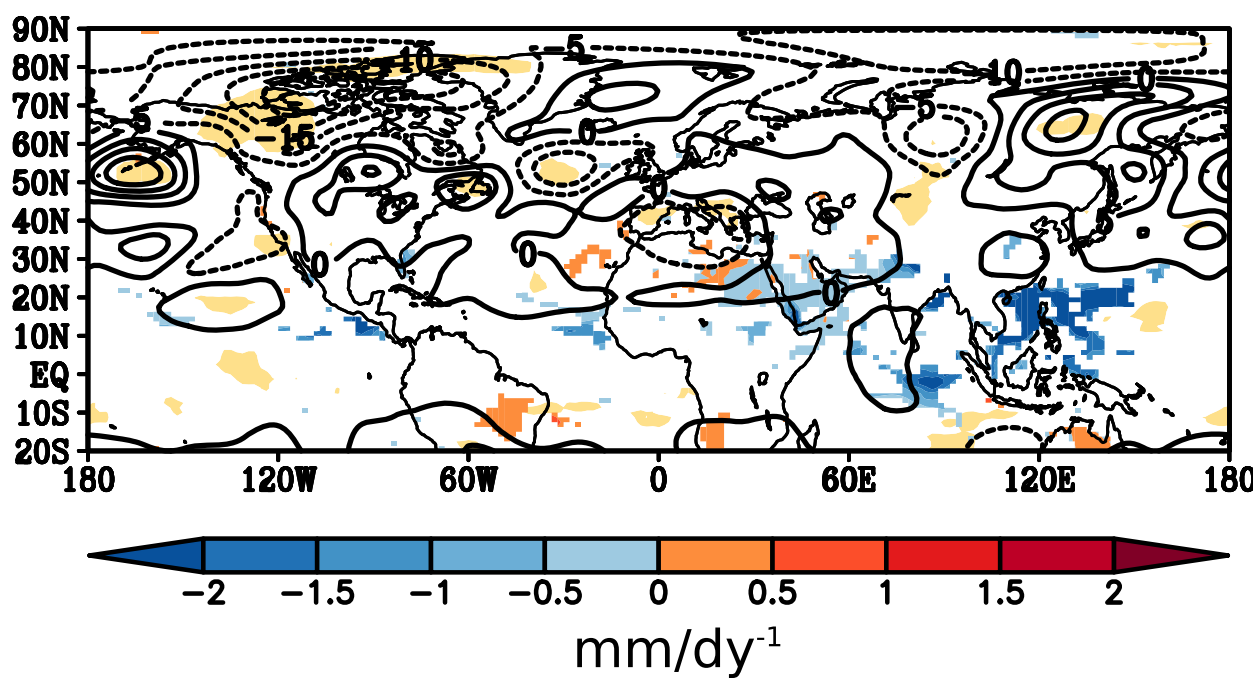

SD of $Z_{250}$ and precipitation, Coupled - Observations

(a)

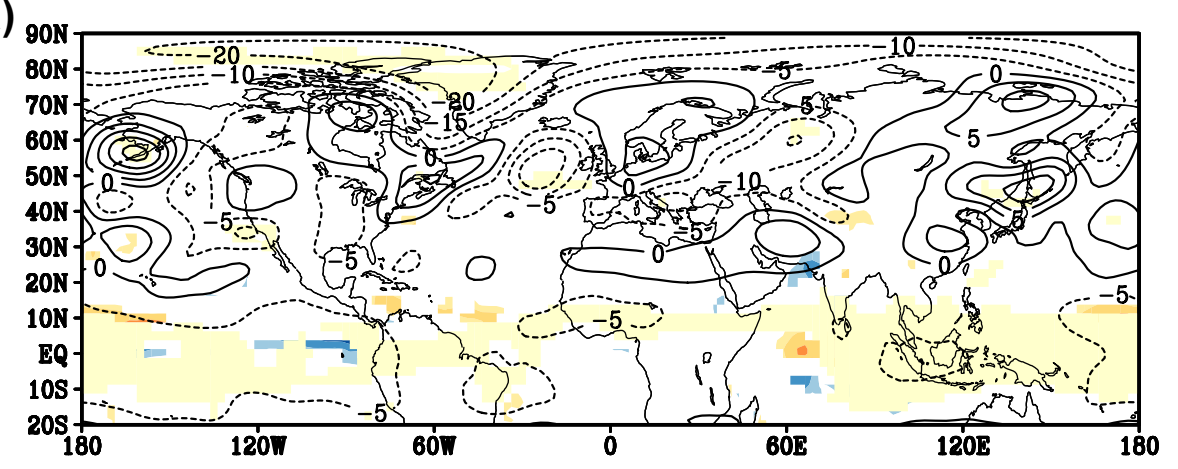

(b)

SD of $Z_{250}$ and precipitation, Uncoupled - Observations

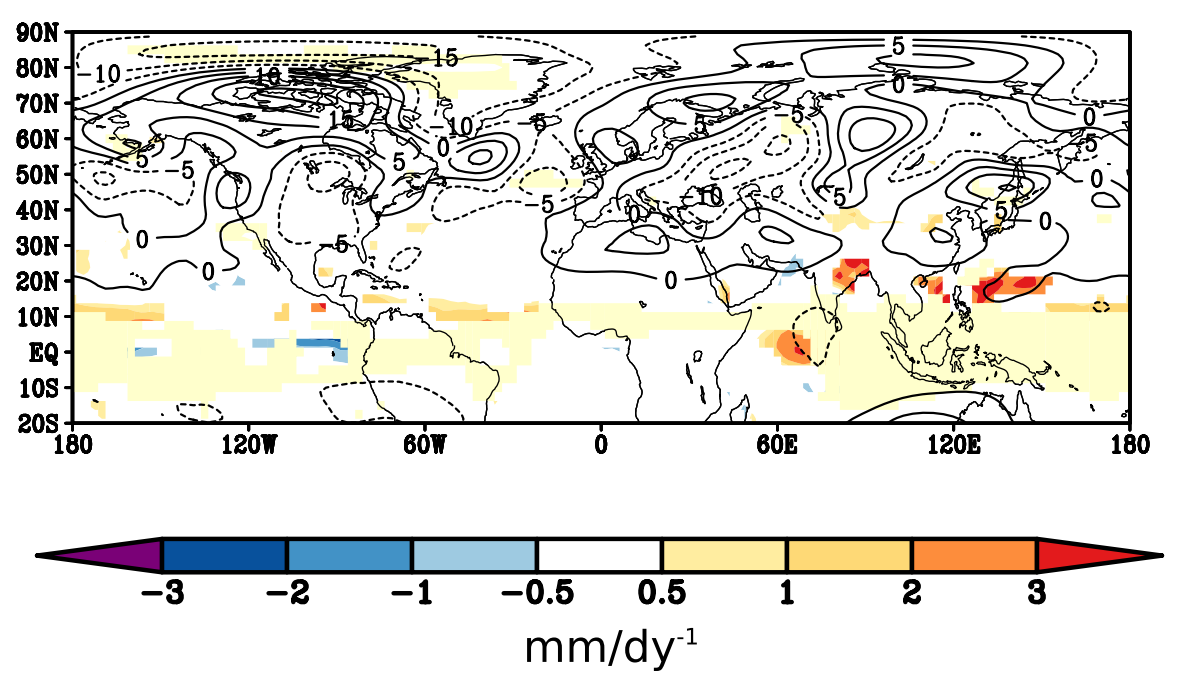


Fig. 7 Local correlation coefficients between seasonal-mean (JJA) SST and precipitation anomalies (shading) for a the ERA-Interim and GPCP datasets, $\mathbf{b}$ the coupled and $\mathbf{c}$ the uncoupled experiments. Stippling indicates the correlation coefficients that are statistically significant at the $95 \%$ level

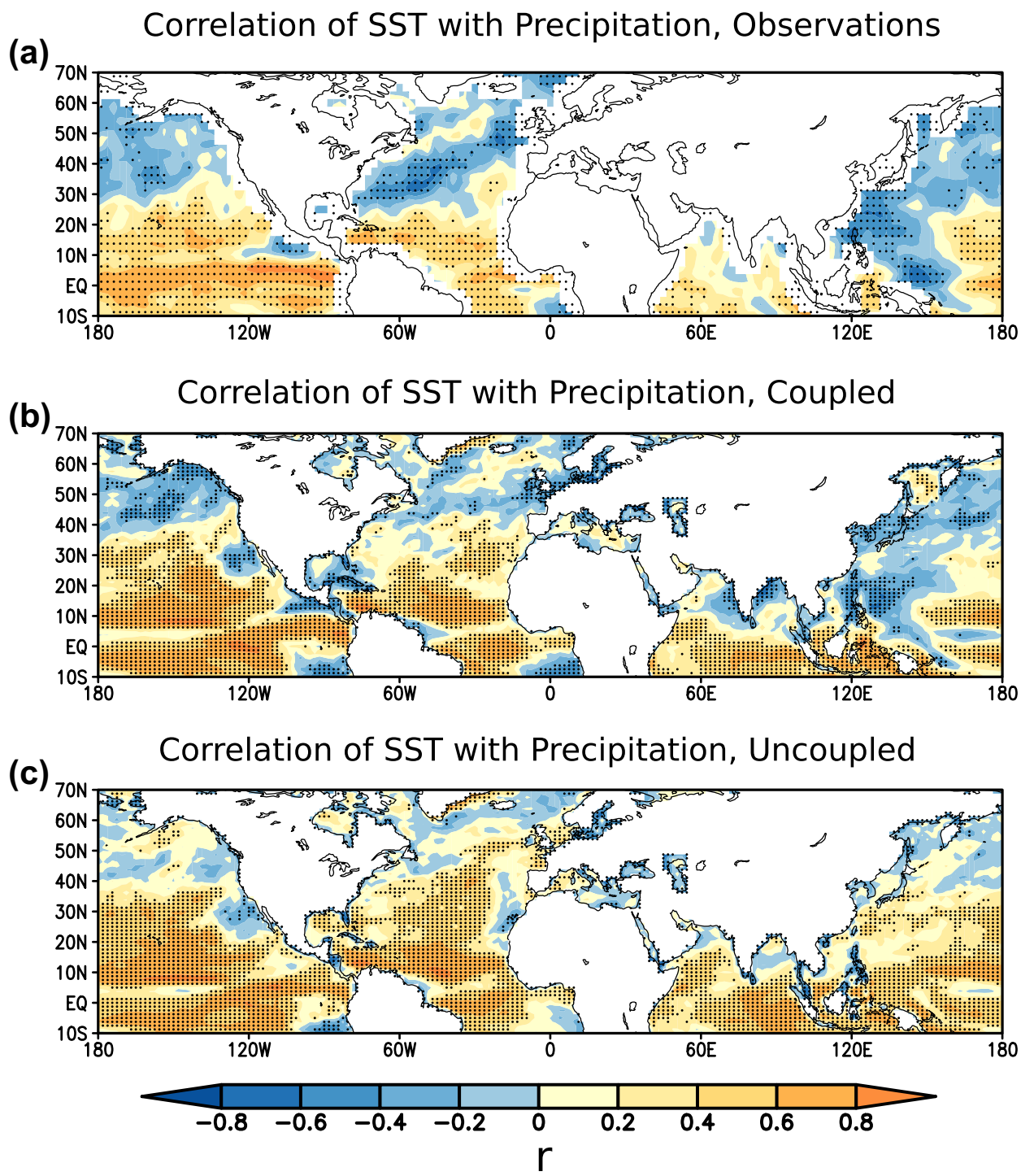

suppresses convection and favors clearer skies leading to increased surface shortwave and hence warmer SSTs. These tropical areas characterized by negative correlations are not apparent in the uncoupled experiment (Fig. 7c) which correlation pattern is positive almost everywhere. Large negative correlations in the observations (Fig. 7a) are apparent as well along the Pacific and Atlantic storm track, indicating the feedbacks of storm track variability on the ocean. The coupled experiment also exhibits negative correlations along the storm track (Fig. 7b), although the magnitude is smaller than in the observations.

\section{The monsoon-desert teleconnection}

This section investigates the impact of air-sea interactions on the representation of the monsoon-desert teleconnection found in RH96 (Sect. 5.1). In Sect. 5.2 the climate impacts of the Indian Monsoon over Europe are analysed. 
Fig. 8 Linear regression coefficients of JJA $\mathrm{Z}_{250}$ anomalies against a JJA precipitation index representative of monsoon precipitation for a the observations, $\mathbf{b}$ the coupled and $\mathbf{c}$ the uncoupled experiments. The precipitation index is calculated by averaging the JJA precipitation for the observations and the model experiments over the black box centered in the Bay of Bengal (spanning $70^{\circ} \mathrm{E}-105^{\circ} \mathrm{E}$, $\left.8^{\circ} \mathrm{N}-35^{\circ} \mathrm{N}\right)$. Contours interval is $4 \mathrm{~m} /\left(\mathrm{mm} \mathrm{day}^{-1}\right)$. Yellow shading indicates the regression coefficients that are statistically significant at the $95 \%$ level

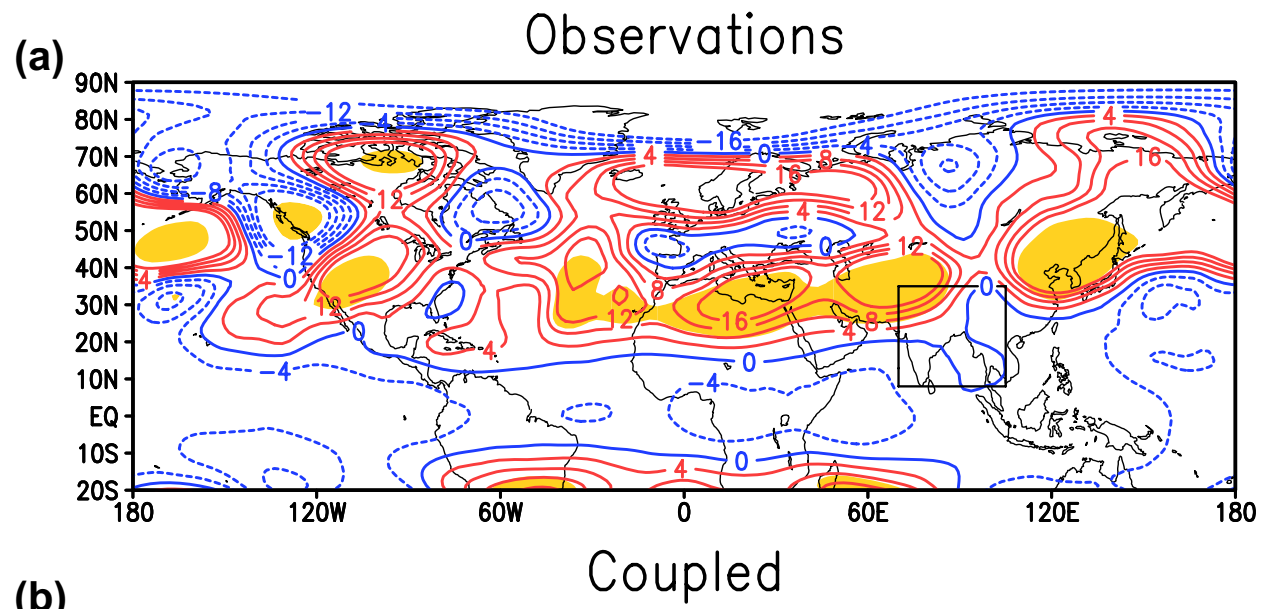

(b)

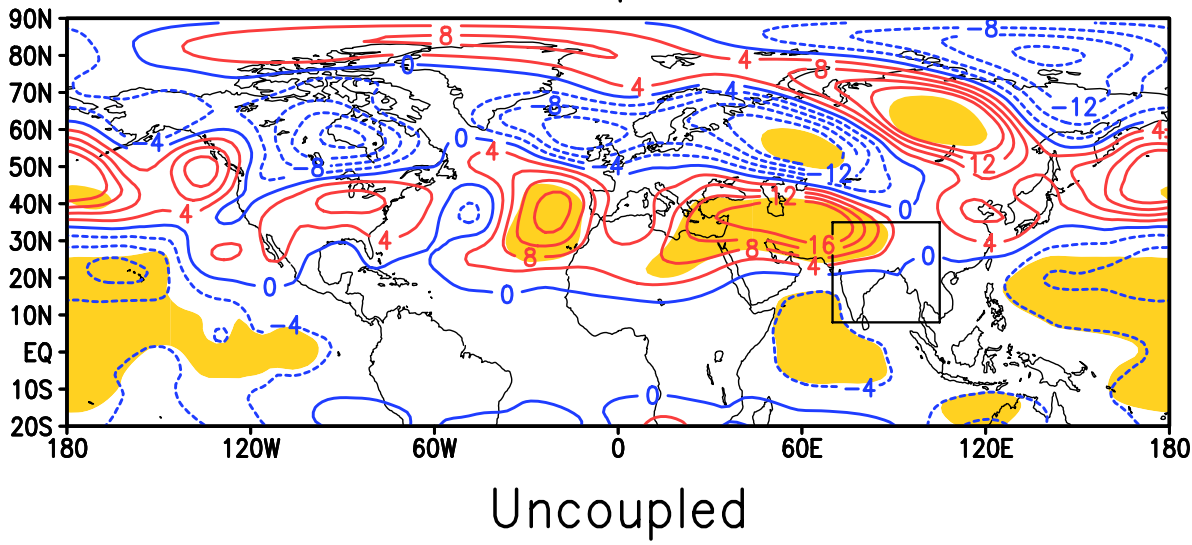

(c)

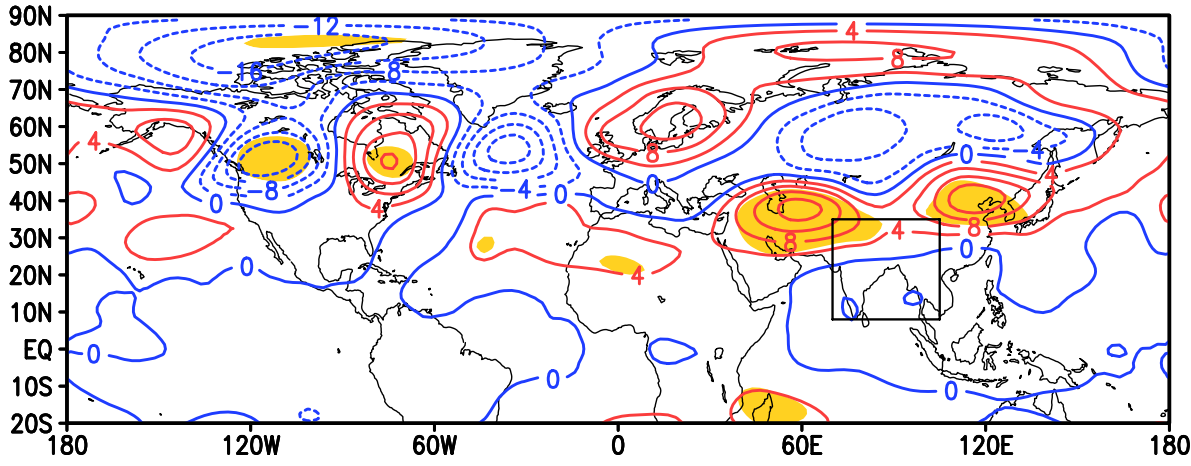

\subsection{The impact of air-sea interaction on the monsoon-desert teleconnection}

Figure 8 shows JJA $\mathrm{Z}_{250}$ regressed against a JJA precipitation index representative of monsoon precipitation for the observations, the coupled and uncoupled experiments (Fig. 8a-c respectively). The index is calculated by averaging the JJA precipitation for the observations and the model experiments over a box centred in the Bay of Bengal $\left(70^{\circ} \mathrm{E}-105^{\circ} \mathrm{E}, 8^{\circ} \mathrm{N}-35^{\circ} \mathrm{N}\right)$. Note that the regression patterns shown in Fig. 8 are largely insensitive to the exact definition of the chosen box.

Figure $8 \mathrm{a}$ indicates that the observed Indian monsoon precipitation is significantly associated with anticyclonic anomalies that extend from the Azores region to the Caspian Sea. This is consistent with the arguments of RH96, i.e., that diabatic heating over the Indian subcontinent excites a westward propagating stationary Rossby Wave, which interacts with the subtropical jet and induces descent over Persia and the Eastern Mediterranean. Figure $8 \mathrm{~b}$ indicates that the monsoon-desert teleconnection is well represented in the coupled experiment. However, the response in the uncoupled experiment (Fig. 8c) is much more local and does not capture the magnitude of the observed teleconnection over the Eastern Mediterranean. The structures of midlatitude regression patterns in Fig. 8 are also different. Although these differences are not statistically robust, their influence on the monsoon itself cannot 
Fig. 9 Linear regression coefficients of JJA $\mathrm{W}_{500}$ (vertical velocity at $500 \mathrm{hPa}$ ) anomalies $\left[-1 \times 10^{-2}\left(\mathrm{~Pa} \mathrm{~s}^{-1} / \sigma\right)\right]$ with a JJA precipitation index representative of monsoon precipitation for $\mathbf{a}$ the observations, $\mathbf{b}$ the coupled and $\mathbf{c}$ the uncoupled experiments. Regressions coefficients are multiplied by $(-1)$, so the blue shading indicates decent and the red ascend. The precipitation index is calculated as in Fig. 8. Stippling indicates the regression coefficients that are statistically significant at the 95\% level

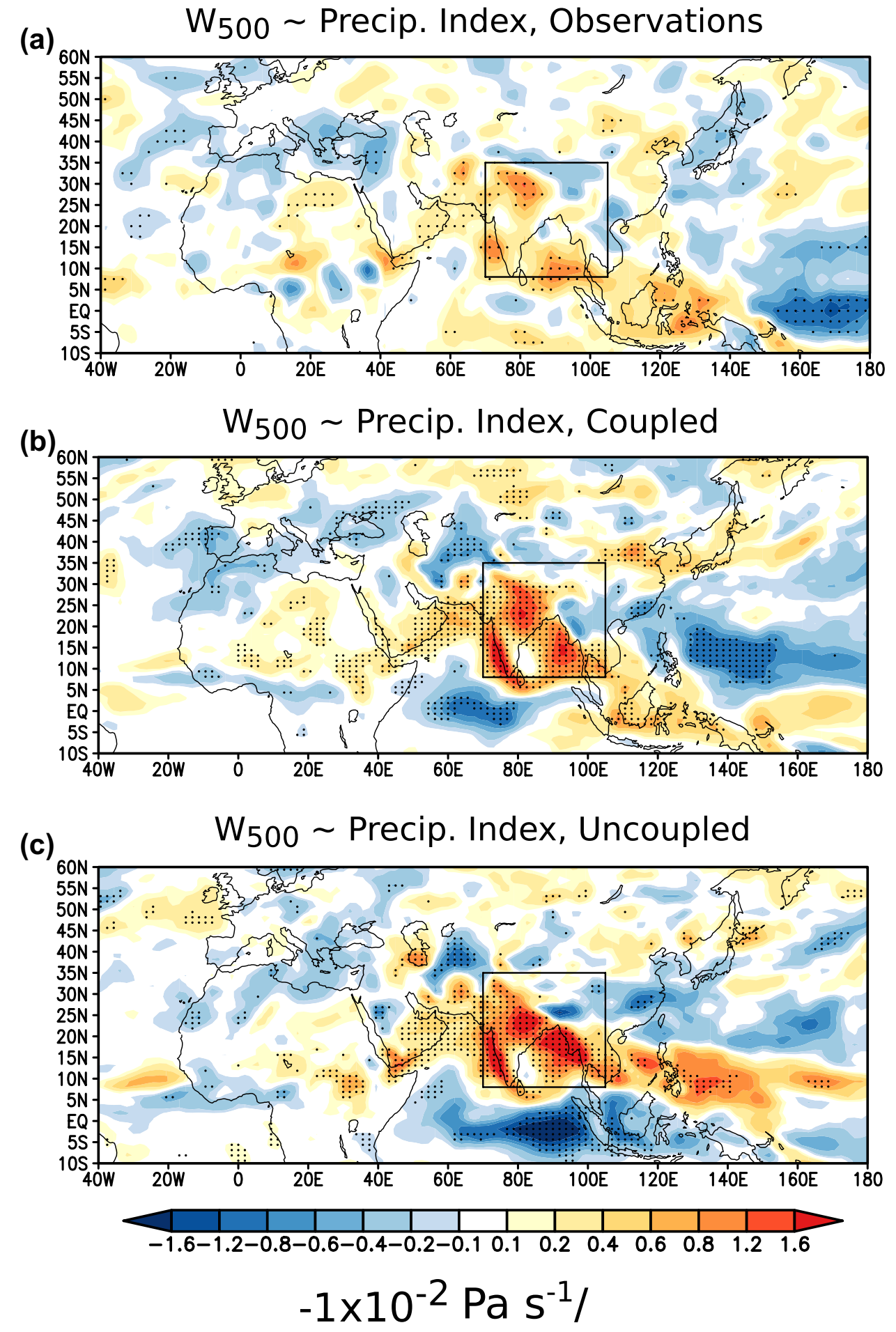

(b)

(c) be discarded entirely. RH96 suggested that enhanced descent west of the Iberian Peninsula and over the East Mediterranean is a key fingerprint of the desert-monsoon teleconnection. Figure 9 shows the vertical velocity at $500 \mathrm{hPa}$ regressed against the JJA precipitation index for the observations (Fig. 9a), the coupled (Fig. 9b) and the uncoupled (Fig. 9c) experiments. Consistent with the areas identified by RH96, the observations exhibit enhanced decent to the west of the Iberian Peninsula and over the eastern Mediterranean region. A similar pattern is apparent for the coupled experiment in Fig. 9b, although the descent over the eastern Mediterranean region is located slightly poleward, consistently with the poleward jetstream bias of the experiments. In the uncoupled model, 
(a)
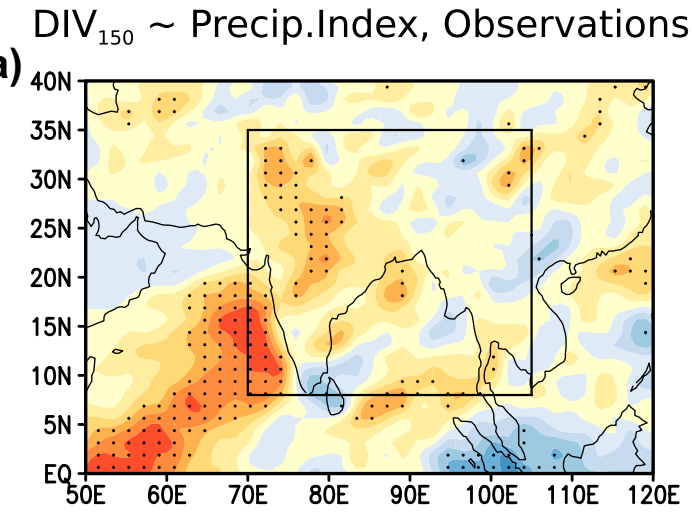

(b)

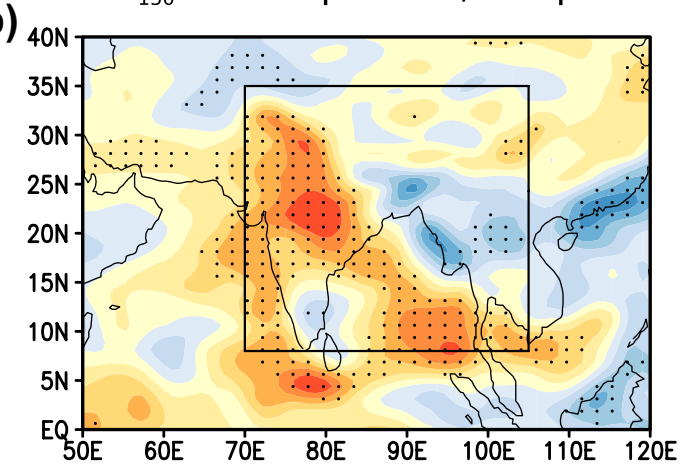

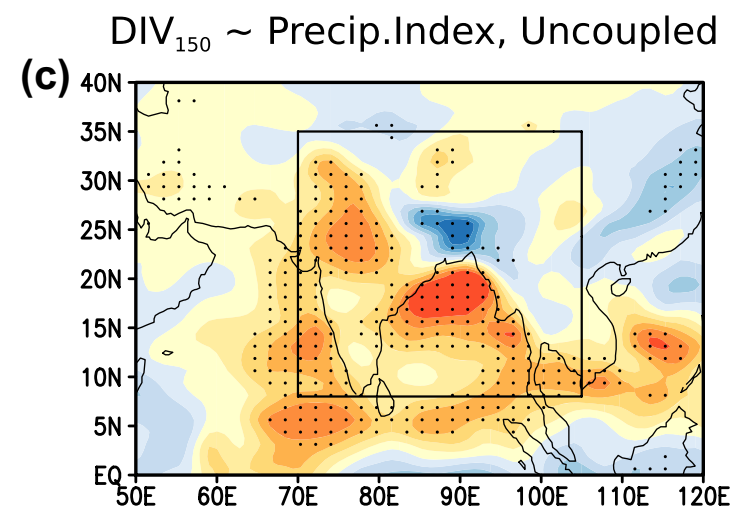

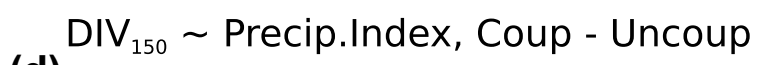

(d)
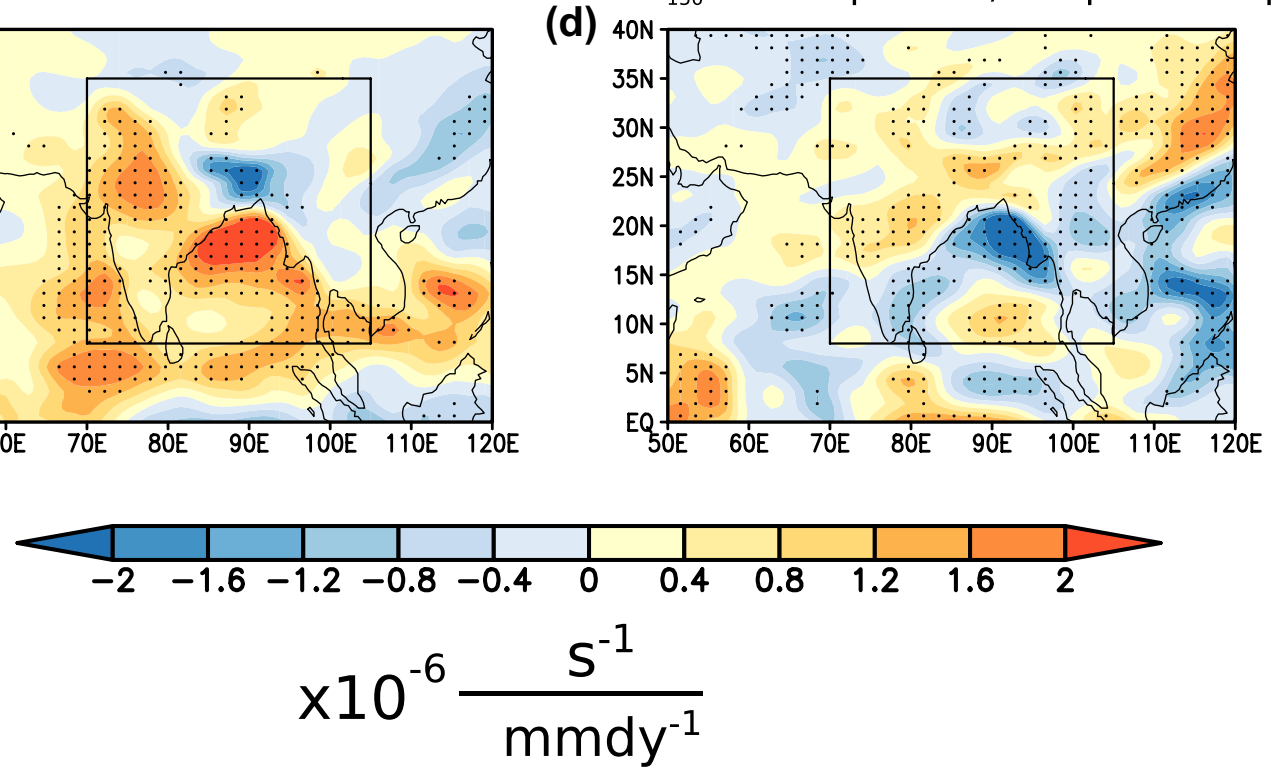

Fig. 10 Linear regression coefficients of JJA divergence anomalies $\left[\mathrm{s}^{-1} /\left(\mathrm{mm} \mathrm{day}^{-1}\right)\right]$ with a JJA precipitation index representative of monsoon precipitation for $\mathbf{a}$ the observations, $\mathbf{b}$ the coupled and $\mathbf{c}$ the uncoupled experiment. d Difference between the coupled and uncou-

the descent is weaker, not statistically significant and confined over the eastern Mediterranean region.

A key question is why are air-sea interactions improving the model representation of the monsoon-desert teleconnection? Figure 10 displays the spatial pattern of divergence at $150 \mathrm{hPa}$ regressed against the JJA precipitation index used in Fig. 8 for the observations (Fig. 10a), the coupled (Fig. 10b) and the uncoupled (Fig. 10c) experiments and the difference between them (Fig. 10d). The divergence anomaly east of North India and the North Bay of Bengal is substantially larger (about $50 \%$ over Northeast India) in the coupled than in the uncoupled experiment, while in the uncoupled experiment the divergence anomaly is much larger over the ocean in the Bay of Bengal and the Philippines. Strong divergence inland is critical since to induce Rossby wave propagation to pled experiments. The precipitation index is calculated as in Fig. 8 . Stippling in a-c indicate the regression coefficients that are statistically significant at the $95 \%$ level. Stippling in $\mathbf{d}$ indicates regression coefficients that are statistically significantly different at the $95 \%$ level

the west, the upper-level divergence field associated with the ISM has to interact with the westerly jet upstream (RH96). The implication is that the divergence field associated with the ISM in the coupled experiment is more favourable for inducing westward Rossby wave propagation than it is in the uncoupled one.

Figure 11 shows the anomalous low-level wind and SST patterns linearly regressed onto the monsoon precipitation for the observations (Fig. 11a), the coupled (Fig. 11b) and the uncoupled (Fig. 11c) experiment. Figure 11a, b show that monsoon precipitation is associated with an enhancement of the summer monsoonal low-level circulation and enhanced easterlies over the Maritime Continent both in the observations and in the coupled experiment. This circulation pattern gives rise to low-level convergence over Northeast 
Fig. 11 Shading shows the correlations of JJA SST anomalies with the JJA precipitation index for a the observations, $\mathbf{b}$ the coupled and $\mathbf{c}$ the uncoupled experiments. Arrows show the coefficients of the zonal and meridional wind anomalies at $925 \mathrm{hPa}$ regressed onto the precipitation index [units: $\mathrm{m} \mathrm{s}^{-1}$ / $\left.\left(\mathrm{mm} \mathrm{day}^{-1}\right)\right]$. The precipitation index is calculated as in Fig. 8. Stippling indicates the SST correlation coefficients that are statistically significant at the 95\% level

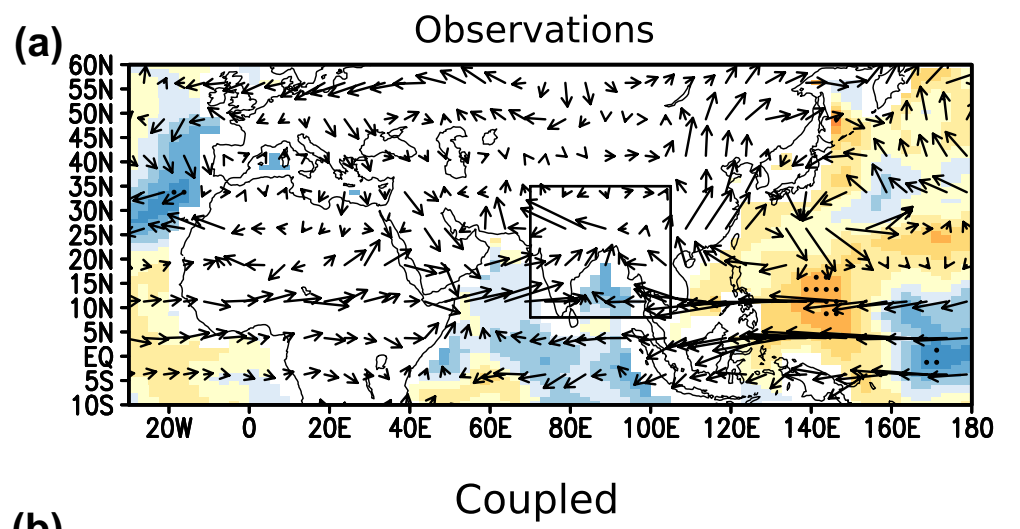

(b)

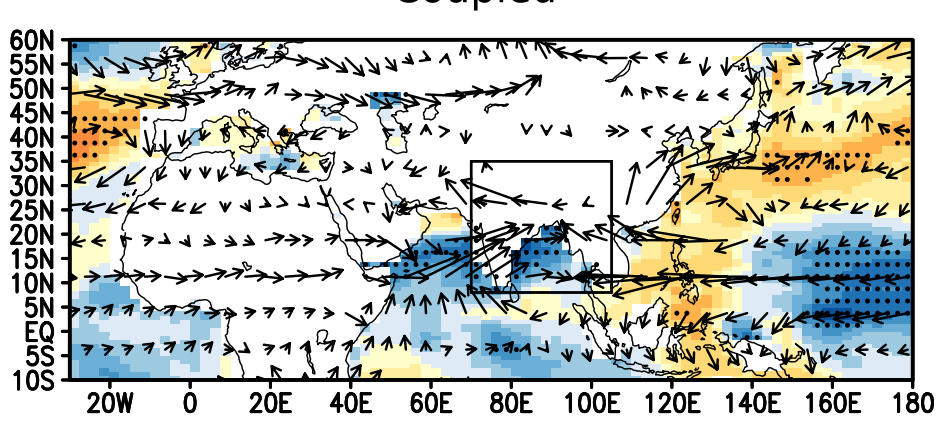

$2 \overrightarrow{m s^{-1} / m m d y^{-1}}$

(c)

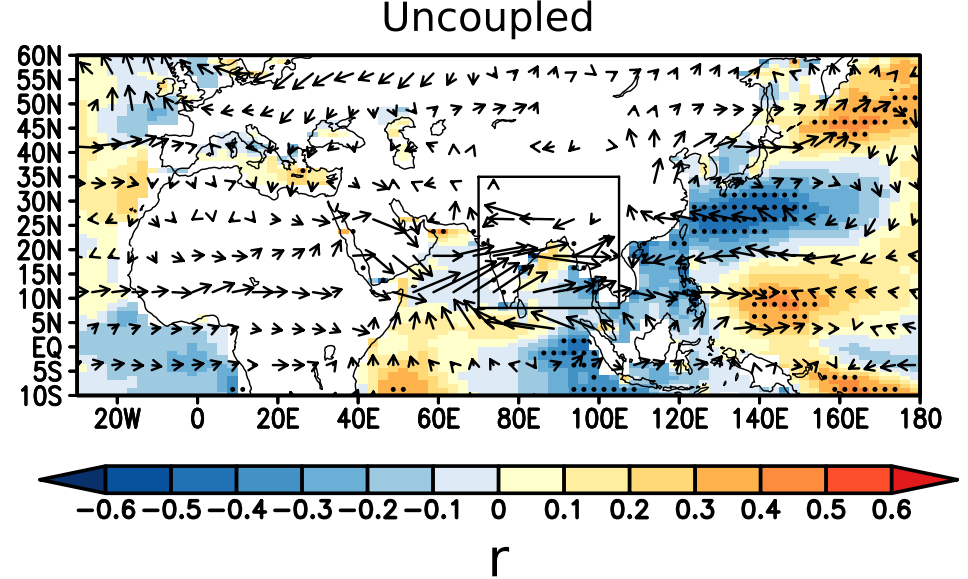

India and the North Bay of Bengal. Monsoon precipitation is also associated with a cold SST anomaly over the Bay of Bengal both in observations and the coupled experiment.

In the uncoupled experiment, the enhancement of the summer monsoonal low-level circulation is also apparent, but enhanced low-level westerlies instead of easterlies are seen over the Bay of Bengal and the Maritime Continent. This circulation pattern results in a reduced low-level convergence over northeast India. Moreover, monsoon precipitation in the uncoupled experiment is associated with a warm SST anomaly over the Bay of Bengal instead of a cold anomaly as in the observations and the coupled experiment. As seen in Fig. 7a, b, both the observations and the coupled experiment exhibit negative correlations between precipitation and SSTs over the Bay of Bengal suggesting air-sea interactions act as a negative feedback on precipitation.
However, in the uncoupled experiment the correlations are positive (Fig. 7c) and the direct link between the warm SST anomaly and precipitation results in too strong rainfall over the Bay of Bengal (see also the upper-level divergence anomaly in the Bay of Bengal in Fig. 9). Too strong rainfall over the Bay of Bengal in the uncoupled experiment appears to be associated with reduced rainfall and upper-level divergence over North East India and the North Bay of Bengal and thus with less favourable conditions for inducing an offequatorial westward Rossby Wave response.

\subsection{Climate impacts of the Indian monsoon over Europe}

Figure 12 shows JJA mean precipitation anomalies regressed against the precipitation index of Fig. 8 for observations 
Fig. 12 Linear regression coefficients of JJA precipitation anomalies $\left[\mathrm{mm} \mathrm{day}^{-1} /\right.$ $\left.\left(\mathrm{mm} \mathrm{day}^{-1}\right)\right]$ with a JJA precipitation index representative of monsoon precipitation for a the observations, $\mathbf{b}$ the coupled and $\mathbf{c}$ the uncoupled experiment. The precipitation index is calculated as in Fig. 8. Stippling indicates the regression coefficients that are statistically significant at the $95 \%$ level

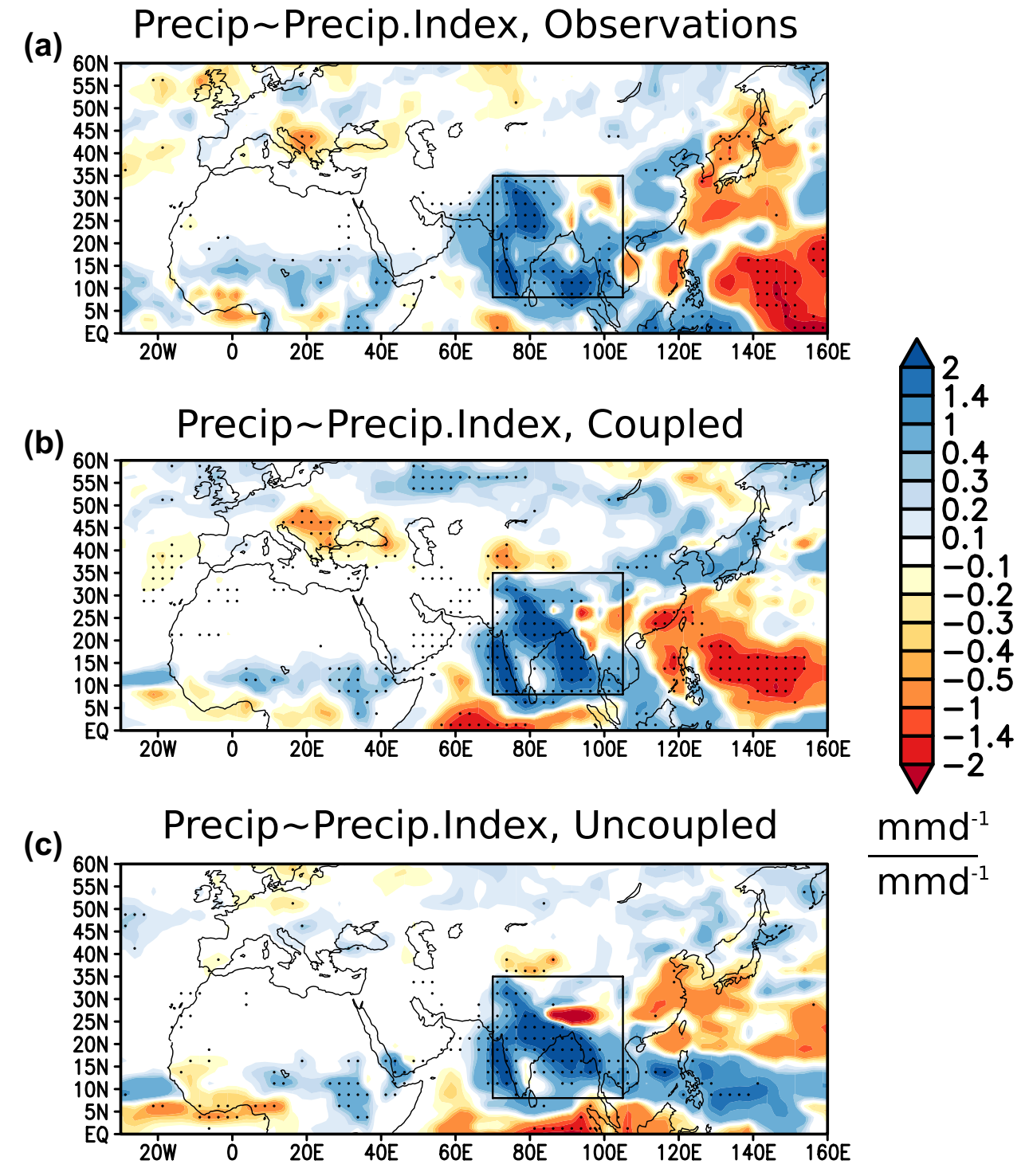

(Fig. 12a), the coupled (Fig. 12b) and the uncoupled experiments (Fig. 12c). There are two broad areas with lower precipitation over the Balkans/Black Sea and off the coast of Portugal in the observations and the coupled experiment. These two regions are collocated with the two centres of descent identified in Fig. 9. The magnitudes of the corresponding correlations (figure not shown) over the Balkans/ Black Sea region are particularly notable $(r>0.6)$. Over this area, the monsoon precipitation accounts for about $40 \%$ of the interannual precipitation variability. This result suggests that a good model representation of this teleconnection could be critical to improving the seasonal precipitation forecasts over this area. To investigate influences from other tropical regions, we have regressed seasonal mean rainfall anomalies against seasonal-mean rainfall anomalies averaged over other areas with strong tropical precipitation such as the Caribbean Sea, the Tropical Atlantic, and the Central and East Pacific Ocean (not shown). No other region besides the Indian monsoon region significantly correlates with the precipitation over these two areas. However, the impact of some other extratropical forcing suppressing the precipitation over these two areas could not be discounted entirely.

\section{Summary}

In this study, we have assessed the impact of air-sea interactions during summer on the atmospheric mean state, interannual variability and the monsoon-desert teleconnection by analyzing two 50-year experiments with the MetUMGOML1 coupled atmosphere-ocean mixed layer model. The main findings of this study are:

- The coupled experiment has a substantially more realistic representation of interannual precipitation variability. Suppressed air-sea interactions in the uncoupled experi- 
ment result in large biases of interannual variability of precipitation. In the uncoupled experiment the precipitation variability over the summer monsoon regions of southern Asia, the Philippine Sea, and off the coast of Central America and West Africa is about two times larger than observed.

- Including air-sea interaction results in a more realistic representation of the monsoon-desert teleconnection. Both the observations and the coupled experiment exhibit higher precipitation and associated upper-level divergence over Northeast India. These conditions are more favourable to westward Rossby wave propagation (RH96). In the uncoupled experiment, the inland Indian precipitation and associated upper-level divergence is much weaker, which appears to be associated with warm SST anomaly and enhance precipitation over the ocean in the Bay of Bengal, which is not seen in the observations or the coupled experiment.

- Both the observations and the coupled experiment exhibit a robust interannual relationship between the ISM associated precipitation and precipitation over the Balkans/ Black Sea region. Strong ISM precipitation is related with a notable reduction of precipitation over this area. Overall, the ISM precipitation is shown to account for about $40 \%$ of the interannual summer precipitation variability over this area.

A good representation of this teleconnection in climate models may be of importance for seasonal, and future climate projections since changes in the ISM have the potential to exacerbate the warm and dry conditions over the Mediterranean during summer. Further research directions include investigating the impact of North Atlantic variability on the monsoon-desert teleconnection. It is plausible that by modifying the downstream flow, the state of the Atlantic Ocean could influence the propagation of the ISM-forced Rossby wave.

Acknowledgements This work was supported by SummerTIME project funded through the Natural Environment Research Council (NERC, No. NE/M005909/1) "Drivers of variability in atmospheric circulation" programme. AO, LS, BD and RS are supported by the UK National Centre for Atmospheric Science (NCAS) at the University of Reading.

Open Access This article is distributed under the terms of the Creative Commons Attribution 4.0 International License (http://creativeco mmons.org/licenses/by/4.0/), which permits unrestricted use, distribution, and reproduction in any medium, provided you give appropriate credit to the original author(s) and the source, provide a link to the Creative Commons license, and indicate if changes were made.

\section{References}

Adler RF et al (2003) The version-2 global precipitation climatology project (GPCP) monthly precipitation analysis (1979-present). J Hydrometeorol 4(6):1147-1167

Ansari A, Bradley R (1960) Rank-sum tests for dispersions. Ann Math Stat 31(4):1174-1189

Arribas A et al (2011) The GloSea4 ensemble prediction system for seasonal forecasting. Mon Weather Rev 139(6):1891-1910

Bader DC, Covey C, Gutowski Jr. WJ, Held IM, Kunkel KE, Miller RL, Tokmakian RT, Zhang MH (2008) Climate models: an assessment of strengths and limitations. U.S. Climate Change Science Program Synthesis and Assessment Product 3.1. Dept of Energy, Office of Biological and Environ Research, p 124

Bjerknes J (1964) Atlantic air-sea interaction. Advances in Geophysics, vol 10. Academic Press, London, pp 1-82

Bjerknes J (1972) Large-scale atmospheric response to the 1964-65 Pacific Equatorial warming. J Phys Oceanogr 2:212-217

Cassou C (2008) Intraseasonal interaction between the MaddenJulian Oscillation and the North Atlantic Oscillation. Nature 455:523-527

Cherchi A, Annamalai H, Masina S, Navarra A (2014) South Asian summer monsoon and eastern Mediterranean climate: the monsoon-desert mechanism in CMIP5 simulations. J Clim 27:6877-6903

Dee D et al (2011) The ERA-Interim reanalysis: configuration and performance of the data assimilation system. Q J R Meteorol Soc 137:535-597

DeMott A, Stan C, Randall A, Branson D (2014) Intraseasonal variability in coupled GCMs: the roles of ocean feedbacks and model physics. J Clim 27:4970-4995

Dong BW, Sutton RT, Hodges K (2013) Variability of the North Atlantic summer storm track: mechanisms and impacts on European climate. Environ Res Lett 8:034037

Dong B, Sutton RT, Shaffrey L, Klingaman NP (2017) Attribution of forced decadal climate change in coupled and uncoupled oceanatmosphere model experiments. J. Climate 30(16):6203-6223

Gastineau G, Frankignoul C (2015) Influence of the North Atlantic SST Variability on the Atmospheric Circulation during the Twentieth Century. J Clim 28:1396-1416. https://doi.org/10.1175/JCLID-14-00424.1

Gates WL et al (1999) An overview of the results of the atmospheric model intercomparison project (AMIP1). Bull Am Meteorol Soc 80:29-55

Graham NE, Barnett TP, Schlesse U, Bengtsson L (1993) On the role of tropical and mid-latitude SSTs in forcing interannual to interdecadal variability in the winter Northern Hemisphere circulation. J Clim 7:141-1441

Hewitt HT, Copsey D, Culverwell ID, Harris CM, Hill RS, Keen AB, McLaren AJ, Hunke EC (2011) Design and implementation of the infrastructure of HadGEM3: the next generation Met Office climate modelling system. Geosci Model Dev 4:223-253. https:// doi.org/10.5194/gmd-4-223-201

Hirons L, Klingaman N, Woolnough S (2015) MetUM-GOML: a nearglobally coupled atmosphere-ocean-mixed-layer model. Geosci Model Dev 8:363-379

Hirons LC, Klingaman NP, Woolnough SJ (2018) The impact of air-sea interactions on the representation of tropical precipitation extremes. J Adv Model Earth Syst 10:550-559. https://doi. org/10.1002/2017MS001252

Hoskins B, Karoly D (1981) The steady linear response of a spherical atmosphere to thermal and orographic forcing. J Atmos Sci 38:1179-1196

Ineson S, Scaife A (2009) The role of the stratosphere in the European climate response to El Nino. Nat Geosci 2:32-36 
Kitoh A, Arakawa O (1999) On overestimation of tropical precipitation by an atmospheric GCM with prescribed SST. Geophys Res Lett 26:2965-2968

Klingaman NP, Woolnough SJ, Weller H, Slingo JM (2011) The impact of finer-resolution air-sea coupling on the intraseasonal oscillation of the Indian monsoon. J Clim 24:2451-2468

Kripalani R, Oh J, Kulkarni A et al (2007) South Asian summer monsoon precipitation variability: coupled climate model simulations and projections under IPCC AR4. Theor Appl Climatol 90(34):133-159. https://doi.org/10.1007/s00704-006-0282-0

Krishna Kumar K, Hoerling M, Rajagopalan B (2005) Advancing dynamical prediction of Indian monsoon rainfall. Geophys Res Lett 32:L08704. https://doi.org/10.1029/2004GL021979

Lau NC, Nath MJ (1994) A modeling study of the relative roles of tropical and extratropical SST anomalies in the variability of the global atmosphere-ocean system. J Clim 7:1184-1207

Lau NC, Nath MJ (2000) Impact of ENSO on the variability of the Asian-Australian monsoons as simulated in GCM experiments. J Clim 13:4287-4309

Lunneborg C. E. (2005) Ansari-Bradley test. Encyclopedia of statistics in behavioral science

Nakamura H, Sampe T, Goto A, Ohfuchi W, Xie S-P (2008) On the importance of midlatitude oceanic frontal zones for the mean state and dominant variability in the tropospheric circulation. Geophys Res Lett 35:L15709. https://doi.org/10.1029/2008GL034010

Ossó A, Sutton R, Shaffrey L, Dong B (2018) Observational evidence of European summer weather patterns predictable from spring. PNAS 115(1):59-63

Preethi B, Mujumdar M, Kripalani RH et al (2017) Recent trends and teleconnections among South and East Asian summer monsoons in a warming environment. Clim Dyn 48(7-8):2489-2505. https ://doi.org/10.1007/s00382-016-3218-0

Rajendran K, Kitoh A (2006) Modulation of tropical intraseasonal oscillations by ocean-atmosphere coupling. J Clim 19:366-391

Randall DA, Wood RA, Bony S et al (2007) Climate models and their evaluation, ch. 8. In: Solomon S, Qin D, Manning M et al (eds) Climate change 2007: the physical science basis, contribution of working group I to the fourth assessment report of the intergovernmental panel on climate change. Cambridge University Press, Cambridge, pp 589-662

Rayner NA, Parker DE, Horton EB, Folland CK, Alexander LV, Rowell DP, Kent EC, Kaplan A (2003) Global analyses of sea surface temperature, sea ice, and night marine air temperature since the late nineteenth century. J Geophys Res 108(D14):4407. https:// doi.org/10.1029/2002JD002670

Ringer MA et al (2006) The physical properties of the atmosphere in the New Hadley centre global atmospheric model (HadGEM1): part II: global variability and regional climate. J Clim 19:1302-1326

Rodwell MJ, Hoskins BJ (1996) Monsoons and the dynamics of deserts. Q J R Meteorol Soc 122:1385-1404

Santer BD, Wigley TML, Boyle JS, Gaffen DJ, Hnilo JJ, Nychka D, Parker DE, Taylor KE (2000) Statistical significance of trends and trend differences in layer-average atmospheric temperature time series. J Geophys Res Atmos 105:7337-7356

Smith DM, Murphy JM (2007) An objective ocean temperature and salinity analysis using covariances from a global climate model. J Geophys Res 112:C02022

Sperber KR, Annamalai H, Kang IS, Kitoh A, Moise A, Turner A, Wang B, Zhou T (2012) The Asian summer monsoon: an intercomparison of CMIP5 vs. CMIP3 simulations of the late 20th century. Clim Dyn 41:2711-2744

Sutton R, Dong B (2012) Atlantic Ocean influence on a shift in European climate in the 1990s. Nat Geosci 5:788-792

Sutton R, Hodson D (2003) Influence of the Ocean on North Atlantic Climate Variability 1871-1999. J Clim 16:3296-3313

Sutton R, Hodson D (2005) Atlantic ocean forcing of North American and European summer climate. Science 309:115-118

Trenberth KE, Branstator GW, Karoly D, Kumar A, Lau N-C, Ropelewski C (1998) Progress during TOGA in understanding and modeling global teleconnections associated with tropical sea surface temperatures. J Geophys Res 103:14291-14324

Tyrlis E, Lelieveld J, Steil B (2013) The summer circulation over the eastern Mediterranean and the Middle East: influence of the South Asian monsoon. Clim Dyn 40:1103-1123

Wallace JM, Rasmusson EM, Mitchell TP, Kousky VE, Sarachik ES, von Storch H (1998) On the structure and evolution of ENSOrelated climate variability in the tropical Pacific: lessons from TOGA. J Geophys Res 103(C7):14241-14260

Walters DN et al (2011) The Met Office Unified Model global atmosphere 3.0/3.1 and JULES global land 3.0/3.1 configurations. Geosci Model Dev 4:919-941

Wang B, Ding Q, Fu X, Kang I-S, Jin K, Shukla J, Doblas-Reyes F (2005) Fundamental challenge in simulation and prediction of summer monsoon rainfall. Geophys Res Lett 32:L15711. https:// doi.org/10.1029/2005GL022734

Wang C, Zhang L, Lee S-K, Wu L, Mechoso CR (2014) A global perspective on CMIP5 climate model biases. Nat Clim Change 4:201-205. https://doi.org/10.1038/nclimate2118

Wills SM, Thompson DWJ, Ciasto LM (2016) On the observed relationships between variability in Gulf Stream Sea surface temperatures and the atmospheric circulation in the North Atlantic. J Clim 29:3719-3730

Woollings T, Hoskins B, Blackburn M, Berrisford P (2008) A new Rossby wave-breaking interpretation of the North Atlantic Oscillation. J Atmos Sci 65:609-626

Woolnough SJ, Vitart F, Balmaseda MA (2007) The role of the ocean in the Madden-Julian Oscillation: implications for MJO prediction. Q J R Meteorol Soc 133:117-128

Wu R, Kirtman BP (2004) The tropospheric biennial oscillation of the monsoon-ENSO system in an interactive ensemble coupled GCM. J Clim 17:1623-1640

Wu R, Kirtman BP (2005) Roles of Indian and Pacific Ocean airsea coupling in tropical atmospheric variability. Clim Dyn 25: $155-170$

Wyrtki K (1973) Teleconnections in the equatorial Pacific Ocean. Science 180:66-68

Wyrtki K (1974) Equatorial currents in the Pacific 1950 to 1970 and their relations to the trade winds. J Phys Oceanogr 4:372-380

Xie SP (2004) Satellite observations of cool ocean-atmosphere interaction. Bull Am Meteorol Soc 85:195-208

Publisher's Note Springer Nature remains neutral with regard to jurisdictional claims in published maps and institutional affiliations. 